\title{
AUDIT PUSKESMAS RAWAT INAP KEDATON
}

(Studi tentang Mengelola Kinerja dan Kapasitas, Mengelola bagian Layanan dan Insiden)

\author{
SALMA SAKINAH \\ 1622050027
}

\author{
Fakultas Ilmu Komputer \\ Jurusan Sistem Informasi \\ Institute Informasi and Business Darmajaya
}

Salma.1611050027@mail.darmajaya.ac.id

\begin{abstract}
Abstrak
Dalam penerapan pelayanan perlu adanya kinerja yang baik dan memiliki kapasitas ruang yang cukup sehingga untuk masa yang akan datang puskesmas bisa menjadi lebih unggul untuk kedepan nya. Dan untuk palayanan jasa harus dilakukan dengan apa yang ditetap kan, apabila terjadinya insiden pihak yang bersangkutan harus berkonfirmasi kepada kepala puskesmas untuk ditindak lanjutkan. Untuk peningkatan derajat kesehatan masyarakat Kota Bandar lampung sangat penting dalam rangka meningkatkan produktivitas masyarakat. Dalam peningkatan pelayanan kesehatan dasar masih terdapat permasalahan, seperti pelayanan kesehatan kepada penduduk masih sangat rendah, masyarakat seringkali mengalami keluhan seperti pelayanan medis, pelayanan obat-obatan, pelayanan administrasi dan pembuatan surat rujukan yang belum memuaskan. Puskesmas Rawat Inap Kedaton merupakan pelayanan kesehatan tingkat pertama yang meraih akreditas sebagai FKTP yang diharapkan dapat memperbaiki dan meningkatkan kesehatan masyarakat khususnya masyarakat .
\end{abstract}

Kata kunci : kinerja pelayanan, prosedur pelayanan, kualitas pelayanan puskesmas. 
